

\title{
Evaluation of Coagulant Aids at High pH
}

\author{
John W. Koenst and Doye E. Blane
}

Issued: April 30, 1976

This report was prepared as an account of work sponsored by the United States Government. Neither the United States nor the United States Energy Research and Development Administration, nor any of their employees, nor any of their. contractors, subcontractors, or their employees, makes any warranty, express or implied, or assumes any legal liability or responsibility for the accuracy, com-

pleteness or usefulness of any information, apparatus, product or process disclosed,

or represents that its use would not infringe privately owned rights.

\section{MONSANTO RESEARCH CORPORATION}

\author{
A Subsidiary of Monsanto Company
}

\section{mOUND IABORPTORY}

Miamisburg, Ohio

45342

operated for

\section{UNITED STATES ENERGY RESEARCH AND DEVELOPMENT ADMINISTRATION}

U. S. Government Contract No. E-33-1-GEN-53 


\section{DISCLAIMER}

Portions of this document may be illegible in electronic image products. Images are produced from the best available original document. 


\begin{abstract}
A series of tests was run on influent to the waste treatment facility, using various polyelectrolytes and organic polymeric coagulant aids. The influent wastewater originates in chemical process areas, janitorial sinks, process-area locker room showers, floor drains, and from the laundry. Previous tests on this waste had shown that $\mathrm{Fe}^{+3}$ and $\mathrm{Ca}^{+2}$ at $\mathrm{pH} 11.3$ gave improved product quality. However, a suitable coagulant aid for use at high $\mathrm{pH}^{\prime} \mathrm{s}$ was needed to obtain a rapid settling rate in the flocculation/sedimentation process. Results of the tests showed that Nalco-C627 gave a good decontamination factor while yielding rapid settling rates. Betz-1175 gave the best decontamination factors; however, its settling rate needs to be improved. Test results revealed decontamination was greater at $\mathrm{pH} 11.3$ than at $\mathrm{pH} 10.1$. It is recommended at this time, that Nalco-C627 be used with the $\mathrm{Fe}^{+3}, \mathrm{Ca}^{+2}$ high $\mathrm{pH}$ system, and that further tests be performed on the Betz-1175.
\end{abstract}

\title{
DISCLAIMER
}

This report was prepared as an account of work sponsored by an agency of the United States Government. Neither the United States Government nor any agency thereof, nor any of their employees, makes any warranty, express or implied, or assumes any legal liability or responsibility for the accuracy, completeness, or usefulness of any information, apparatus, product, or process disclosed, or represents that its use would not infringe privately owned rights. Reference herein to any specific commercial product, process, or service by trade name, trademark, manufacturer, or otherwise does not necessarily constitute or imply its endorsement, recommendation, or favoring by the United States Government or any agency thereof. The views and opinions of authors expressed herein do not necessarily state or reflect those of the United States Government or any agency thereof. 


\section{Introduction}

Impurities in water vary in size by at least six orders of magnitude, namely, from a few Angstroms (for soluble substances) to a few hundred microns (for suspended materials). The removal of large portions of these impurities in wastewater treatment is accomplished by sedimentation. However, because many of the impurities are too small for gravitational settling alone to be an effective removal process, the aggregation of these particles into large, more readily settleable, aggregates is essential for successful separation by sedimentation. This process of aggregation is termed coagulation.

Recognition that the success of other processes for wastewater treatment often involves or depends upon successful coagulation has stimulated a considerable amount of research on this process in the past two decades. New concepts have been deve1oped, and a large quantity of laboratory and field data have been obtained. of principal importance are the new coagulants that have been developed. These materials are synthetic organic polymers having high molecular weights. The application of these new concepts and new materials constitutes a major contribution to the technology of wastewater treatment.

The aggregation of colloidal particles involves two separate and distinct steps: 1) particle transport to effect interparticle contact, and 2) particle destabilization to permit attachment when contact occurs. Theories of particle transport are based on fluid and particle mechanics; theories of particle destabilization are based on colloid and surface chemistry. The design of structures and flocculation equipment for a coagulation process is influenced by a consideration of interparticle contacts; the selection of the type and dosage of coagulant is based on a consideration of particle destabilization. The design of the overall coagulation process must provide for both of these steps.

Despite attempts to apply theory to practice, coagulation remains as much of an art as a science. Theories from the fields of colloid chemistry and fluid mechanics cannot be used alone in the design of coagulation processes; experience and experiments are also required.
Mound Laboratory Waste Disposal System The radioactive waste disposal system currently in operation at Mound Laboratory is the same one originally initiated when the Laboratory first started in October 1948 . Initially, this process was developed at Mound for the removal of $210 \mathrm{Po}$; however, at this time, the main contaminant is $2{ }^{8} \mathrm{Pu}$. The treatment process consists of coagulation, sedimentation, and rapid-sand filtration.

1. Coagulation and Settling Coagulation involves the formation of chemical flocs that bring together finely divided suspended matter. The addition of coagulants will result in the precipitation of some of the soluble constituents in the waste as metal hydroxides. Coagulation is effective for the removal of most cations of valence 3,4 , or 5 , including the rare earths group, and is not effective for the removal of elements of Groups IA and IIA. Coagulation is more effective in removing particulate associated radioactivity, as for example, radioactivity associated with the turbidity found in most wastewaters. Organic polyelectrolytes are added to aid in settling the floe. The removal of soluble, radioactive, organic complexes, (those adsorbable on carbon) may be enhanced by the addition of activated carbon with the usual coagulants and coagulant aids.

2. Rapid Sand Filtration Except for removal by simple straining or by sorption, sandfilters have been ineffective for removing radioactive materials. Their major function is to remove the radioactivity previously incorporated in the floc. In order to aid filtration and to give supplemental adsorption, activated carbon is added prior to the sandfilter.

The influent wastewater originates in chemical process areas, janitorial sinks, process-area locker room showers, floor drains, and from the laundry. From all of these sources, the wastewater flows to one of four $30,000-g a l$ influent holding tanks. The $\mathrm{pH}$ of the waste stream ranges from 6 to 8 , and the radioactivity level averages about 5000-10,000 $\mathrm{dis} / \mathrm{min} / \mathrm{ml}$. At the present time, about $12,000-15,000$ gal of influent wastewater are processed per day. Since the waste disposal system at Mound Laboratory has. 
not been significantly modified in over $20 \mathrm{yr}$, it was decided to study a modification to the present process that would include treatment at a higher $\mathrm{pH}$ (from 8 to 11.3) along with the use of an alternate polymeric coagulant aid (since the presently used coagulant aid is ineffective at $\mathrm{pH}$ greater than 10). This modification should reduce the amount of sludge generated and improve effluent quality.

Dosage and Process Control The quality of treated water and the costs of chemicals for its production are dependent on proper control of the coagulation-flocculation process. Laboratory and in-plant control are essential to proper coagulation treatment for two basic reasons: first, plants that employ coagulation usually treat waters that may be subject to wide variations in quality; and second, the best and most economical treatment of such waters cannot be predicted from known relationships but must be checked by one or more testing or monitoring techniques. Coagulation and flocculation of wastewater are influenced by a number of interrelated factors such as $\mathrm{pH}$, color, turbidity, mineral content and composition, temperature, and duration and degree of agitation during flocculation, and finally, the characteristics of the coagulant or flocculation aid in use. Unfortunately, the optimum conditions for coagulation cannot be determined from the results of a chemical and physical analysis of the wastewater but must be determined empirically.

The single most widely used test to determine dosage and other parameters at Mound Laboratory is the "jar test." The jar test attempts to simulate the full-scale coagulation-flocculation process and has remained the most common control test in this laboratory since its introduction. The jar test simply consists of a series of sample containers, the contents of which can be stirred by individual mechanically-operated stirrers. The wastewater, which is to be treated, is placed in the container; and the treatment chemicals are added while the contents are being stirred. After a short ( 1 to $5 \mathrm{~min}$ ) period of rapid stirring, to ensure complete dispersion, the stirring rate is decreased and flocculation is allowed to continue for a variable period (10 to $30 \mathrm{~min}$ or more). The stirring is then stopped, and the flocs are allowed to settle for a selected time. The supernatant is then filtered (to simulate sandfilter operation) and analyzed for a variety of parameters.

\section{Results}

A series of tests were run on raw influent using various polyelectrolytes and organic polymeric coagulant aids. Previous tests had shown that $\mathrm{Fe}^{+3}$ and $\mathrm{Ca}^{+2}$ at $\mathrm{pH} 11.3$ gave improved effluent quality (Table 1). However, for comparison purposes, alum $\left(\mathrm{A} 1^{+3}\right)$ treated influent was tested at $\mathrm{pH}$ 6.3 and 4.8 with such coagulant aids as aluminosilicate complex (expressed in ppm $\mathrm{SiO}_{2}$ ), cationic polymeric coagulant aids, and nonionic polymeric coagulant aids

(Tables 2 and 3 ). Using various polymeric coagulant aids (Tables 2 and 3 ), to improve performance of the process and to find a suitable coagulant aid at the higher $\mathrm{pH}$ 's, $\mathrm{Fe}^{+3}$ and $\mathrm{Ca}^{+2}$ were evaluated at $\mathrm{pH} 11.3$ and 10.1. The alum results were disappointing in that decontamination factors were quite low (ranging from a low of 51 to a high of 1183); also, settling rates were very slow and the supernatant remained slightly turbid. As a result, further work with alum was discontinued. Iron $\left(\mathrm{Fe}^{+3}\right)$ and calcium $\left(\mathrm{Ca}^{+2}\right)$ without any coagulant aids gave a $D F \sim 3670$, which was then used as a basis for evaluating the performance of coagulant aids. Iron and calcium by themselves, however, gave a slow settling rate to the floc. The best settling rates were obtained with Nalco-C627 combined with DOW-N20 $(\mathrm{DF}=7339)$. Using $\mathrm{NalCO}-\mathrm{C} 627$ as the sole coagulant aid with $\mathrm{Fe}^{+3}$ and $\mathrm{Ca}^{+2}$, gave a $D F=13,333$ along with a good settling rate. However, the supernatant had a slightly cloudy appearance, which was subsequently filtered out by the $2 \mu$ filter. Tests revealed decontamination at $\mathrm{pH}$ 1l. 4 was greater than at $\mathrm{pH} 10.1$, using the same coagulant aids. DF's obtained were $\mathrm{DF}=3126$ at $\mathrm{pH} 10.1$ and $\mathrm{DF}=7340$ at $\mathrm{pH} 11.4$. Both tests were run on the same influent feed, using Nalco-C627 and DOW-N2O as coagulant aids. The best decontamination factors were obtained using Betz polymers. Betz-1190 demonstrated a DF $-168,800$, whereas Betz-1175 resulted in a supernatant that measured less than background. However, the two Betz polymers settled at a slower rate than the Nalco-C627. The settling rates of the Betz polymers were, however, greater than that of $\mathrm{Fe}^{+3}$ and $\mathrm{Ca}^{+2}$ without coagulant aid.

In summary, it is recommended that Nalco$\mathrm{C} 627$ be used with the high $\mathrm{pH}\left(\mathrm{Fe}^{+3}, \mathrm{Ca}^{+2}\right)$ system. However, clarifier performance (with respect to sludge settling characteristics and carry-over) and filter performance (with respect to removal of the remaining cloudy appearance in the supernatant) will be carefully monitored. Also, further studies on improving the settleability of the Betz-1175 (without greatly sacrificing DF) will be continued. 
Table 1

RESULTS OF ELEVATED PH TREATMENT

$\begin{array}{llll}\text { Feed } & \text { pH } & \text { Filtration } & \begin{array}{c}\text { Final Effluent } \\ (\mathrm{dis} / \mathrm{min} / \mathrm{ml})\end{array} \\ \begin{array}{l}\text { Effluent from Mix Box } \\ \text { Supernatant from }\end{array} & 6.7 & 9 \text { in. sand } & 4.1 \\ \begin{array}{l}\text { Clariflocculator } \\ \text { (Elevated to pH 11.3) }\end{array} & 11.3 & 9 \text { in. sand } & 0.46\end{array}$

Table 2

COAGULANT AIDS USED IN TREATABILITY STUDY

Actasol

Betz 1175

Betz 1190

Dow C31

Dow $\mathrm{N} 20$

Nalco C610

Nalco 6627
Complex aluminosilicate form (reported as $\mathrm{SiO}_{2}$ )

High molecular weight, strongly cationic, organic polyelectrolyte

Strongly cationic, polymeric polyelectrolyte

High molecular weight, cationic, organic polyelectrolyte High molecular weight, nonionic, organic polyelectrolyte Cationic, organic polyelectrolyte

Cationic, organic polyelectrolyte 
Table 3

TREATABIIITY STUDY

\begin{tabular}{|c|c|c|c|c|c|c|c|c|}
\hline $\begin{array}{c}\text { Test } \\
\text { No. }\end{array}$ & Date & $\begin{array}{c}\text { Raw } \\
\text { Influent } \\
\text { Counts } \\
(\mathrm{dis} / \mathrm{min} / \mathrm{ml}) \\
\end{array}$ & $\begin{array}{l}\text { Initial } \\
\mathrm{pH} \\
\end{array}$ & $\begin{array}{c}\text { Electrolytes } \\
(\mathrm{ppm})\end{array}$ & $\begin{array}{l}\text { Coagulant } \\
\text { Aids } \\
\text { (ppm) } \\
\end{array}$ & $\begin{array}{l}\text { Adjusted } \\
\mathrm{pH} \\
\end{array}$ & $\begin{array}{c}\text { Supernatant after } \\
\text { settling and } 2 \mu \\
\text { Filtration } \\
(\text { dis } / \mathrm{min} / \mathrm{ml}) \\
\end{array}$ & $\mathrm{DF}=\frac{\text { Influent Counts }}{\text { Supernatant Counts }}$ \\
\hline 1 & $4 / 29$ & 2000 & 7.5 & $A I^{+3}(100)$ & $\mathrm{SiO}_{2}(30)$ & 6.2 & 2.02 & 990 \\
\hline 2 & $4 / 29$ & 2000 & 7.5 & - & - & - & 39.33 & 51 \\
\hline 3 & $4 / 29$ & 2000 & 7.5 & $\mathrm{Al}^{+3}(100)$ & - & 6.3 & 1.69 & 1183 \\
\hline 4 & $4 / 29$ & 2000 & 7.5 & $\mathrm{Al}^{+3}(100)$ & $\begin{array}{l}\mathrm{SiO}_{2}(30 \\
\mathrm{C} 31(5) \\
(\mathrm{N} 20(7)\end{array}$ & 4.8 & 7.28 & 275 \\
\hline 5 & $4 / 29$ & 2000 & 7.5 & $\begin{array}{l}\mathrm{Fe}^{+3}(100) \\
\mathrm{Ca}^{+2}(200)\end{array}$ & C610(10) & 11.35 & 0.6 & 3333 \\
\hline 6 & $4 / 29$ & 2000 & 7.5 & $\begin{array}{l}\mathrm{Fe}^{+3}(100) \\
\mathrm{Ca}^{+2}(200)\end{array}$ & C6 $27(20)$ & 11.35 & 0.15 & 13333 \\
\hline 7 & $4 / 29$ & Added 2 ppm N20 & to No. 6 & and remixed & & & 0.5 & 4000 \\
\hline 8 & $4 / 29$ & 2000 & 7.5 & $\begin{array}{l}\mathrm{Fe}^{+3}(100) \\
\mathrm{Ca}^{+2}(200)\end{array}$ & $\mathrm{SiO}_{2}(50)$ & 11.35 & 0.37 & 5405 \\
\hline 9 & $4 / 30$ & 1688 & 8.1 & $\begin{array}{l}\mathrm{Fe}^{+3}(100) \\
\mathrm{Ca}^{+2}(200)\end{array}$ & $\begin{array}{l}\mathrm{C} 627(10) \\
\mathrm{N} 20(2)\end{array}$ & 11.4 & 0.23 & 7339 \\
\hline 10 & $4 / 30$ & 1688 & 8.1 & $\begin{array}{l}\mathrm{Fe}^{+3}(100) \\
\mathrm{Ca}^{+2}(200)\end{array}$ & Betz $1190(20)$ & 11.4 & 0.01 & 168800 \\
\hline 11 & $4 / 30$ & 1688 & 8.1 & $\begin{array}{l}\mathrm{Fe}^{+3}(100) \\
\mathrm{Ca}^{+2}(200)\end{array}$ & Betz $1175(20)$ & 11.4 & $<$ Background & $\infty$ \\
\hline 12 & $5 / 1$ & 1688 & 8.1 & $\begin{array}{l}\mathrm{Fe}^{+3}(100) \\
\mathrm{Ca}^{+2}(200)\end{array}$ & - & 11.4 & 0.46 & 3670 \\
\hline 13 & $5 / 1$ & 1688 & 8.1 & $\begin{array}{l}\mathrm{Fe}^{+3}(100) \\
\mathrm{Ca}^{+2}(200)\end{array}$ & $\begin{array}{l}\mathrm{C} 627(10) \\
\mathrm{N} 20(2)\end{array}$ & 10.1 & 0.54 & 3126 \\
\hline 14 & $5 / 1$ & 1688 & 8.1 & $\begin{array}{l}\mathrm{Fe}^{+3}(100) \\
\mathrm{Ca}^{+2}(200)\end{array}$ & $\begin{array}{l}\text { Betz } 1175(20) \\
\text { N20 (2) }\end{array}$ & 11.4 & 0.18 & 9378 \\
\hline
\end{tabular}


DISTRIBUTION

\section{Externa1}

J. A. Chacon, ERDA/DAO

N. H. MacKay, ERDA/ALO

R. A. Wolfe, ERDA/DNFCP

Internal

D. E. Blane

W. T. Cave

I. V. Jones

D. P. Kelly

H. W. Kirby

J. W. Koenst, Jr.

B. R. Kokenge

E. I. Murphy

I. B. Stevens

J. E. Todd

R. E. Vallee

J. G. Villars (2)

Document Control

Library (15)

Publications 